\title{
Evaluation of lipid accumulation from lignocellulosic sugars by Mortierella isabellina for biodiesel production
}

\author{
Zhenhua Ruan ${ }^{a}$, Michael Zanotti ${ }^{a}$, Xiaoqing Wang ${ }^{a}$, Chad Ducey ${ }^{b}$, Yan Liu ${ }^{a, *}$ \\ ${ }^{a}$ Department of Biosystems and Agricultural Engineering, Michigan State University, East Lansing, MI 48824, USA \\ be-Biofuels, LLC Middletown, IN 47356, USA
}

\section{A R T I C L E I N F O}

\section{Article history:}

Received 13 October 2011

Received in revised form 11 January 2012

Accepted 12 January 2012

Available online 28 January 2012

\section{Keywords:}

Mortierella isabellina

Diluted acid and alkaline pretreatments

Enzymatic hydrolysis

Hydrolysate of corn stover

Filamentous fungal lipid fermentation

\begin{abstract}
A B S T R A C T
The filamentous fungus Mortierella isabellina ATCC42613 was used to assess the conversion of different carbon sources (glucose, xylose, mixed glucose/xylose, acid and alkali treated corn stover hydrolysate) in submerged media to lipid. Glucose and xylose cultures composed of varying initial sugar concentrations (28.1-91.7 $\mathrm{g} \mathrm{L}^{-1}$, and 26.6-90.9 $\mathrm{g} \mathrm{L}^{-1}$ respectively) showed a positive correlation to lipid accumulation, with significant quantities occurring at the upper limit of the substrate range $\left(10.2\right.$, and $8.8 \mathrm{~g} \mathrm{~L}^{-1}$ lipid respectively). While lipid concentrations increased with each incremental glucose and xylose level, the lipid yield (0.41-0.44, and $0.39-0.43 \mathrm{~g} \mathrm{~g}^{-1}$ cell mass respectively), and intracellular fatty acid composition remained relatively constant. Additionally, sulfuric acid hydrolysate, without detoxification, exhibited greater cell mass, and equivalent lipid production compared to synthetic medium with similar initial glucose and xylose concentrations. These results elucidate the potential of utilizing filamentous fungal fermentation to accumulate lipids from lignocellulosic biomass for biodiesel production.
\end{abstract}

(c) 2012 Elsevier Ltd. All rights reserved.

\section{Introduction}

Biodiesel is viewed as an attractive alternative to diesel fuel due to its positive environmental characteristics. It is non-toxic, biodegradable, has a favorable emissions profile, and is produced from a variety of renewable resources including: soybean, palm, sunflower, rapeseed, jatropha, and waste oils (Al-Widyan and Al-Shyoukh, 2002; Bouaid et al., 2007). However, growing concerns over the use of food crops for fuel production, as well as the rising global energy demand has put pressure on the biodiesel industry to find alternative sources of oil. Attention has shifted to non-edible oil sources such as those produced from oleaginous microorganisms (those organisms with lipid content in excess of $20 \%$ ). Microbial lipids are viewed as a possible alternative for industrial production because their fatty acid composition is similar to that of vegetable oils, as well as the fact that they are rich in polyunsaturated fatty acids, such as $\gamma$-linolenic acid, which are often used in dietary supplements and for infant nutrition (Huang et al., 2009). The major fatty acids present in the lipids produced by oleaginous microorganisms are myristic acid (C14:0), palmitic acid (C16:0), stearic acid (C18:0), oleic acid (C18:1), linoleic acid (C18:2), and linolenic acid (C18:3); all of which can be converted to biodiesel through a transesterification reaction.

\footnotetext{
* Corresponding author. Tel.: +1 517432 7387; fax: +1 5174322892.

E-mail address: liuyan6@msu.edu (Y. Liu).
}

However, the limiting factor for microbial lipid production is often the organism's low productivity coupled with the high expense of its glucose substrate (Lin et al., 2010). In order to overcome cost barriers, a cheaper source of carbon is desired. Lignocellulosic biomass such as corn stover is of great interest due to its abundance and potential to serve as an inexpensive feedstock of mono-sugars for lipid production. Both glucose and xylose can be extracted from such sources, with glucose being the more abundant and easier metabolized of the two. However, large amounts of xylose are also produced during lignocellulosic biomass pretreatment (Lee et al., 1999). Organisms that can utilize both C-5 and C-6 sugars for fermentation are thus highly desired in order to increase the efficiency of lipid production from lignocellulosic materials. The wide availability of lignocellulosic material coupled with their cheap cost and ease of xylose extraction makes them potentially attractive substrates for microbial lipid accumulation.

In general, lipids are accumulated in oleaginous organisms due to the presence of the ATP-dependent citrate lyase. Under nutrient limited conditions, especially nitrogen limitation with an abundant carbon source (high $\mathrm{C} \cdot \mathrm{N}^{-1}$ ratio), AMP deaminase is up-regulated eventually leading to the presence of citrate in the cell cytosol. Citrate is cleaved by the ATP-dependent citrate lyase producing acetyl-CoA, which is used in fatty acid biosynthesis. It is by this pathway that oleaginous microorganisms shift their carbon sources away from growth and toward lipid production (Ratledge, 2004). Though glucose is the more easily assimilated of the two major lignocellulosic carbon sources, studies have investigated oleaginous fungal lipid production using xylose as the carbon 
source as well as both glucose and xylose simultaneously. Xylose $\left(80 \mathrm{~g} \mathrm{~L}^{-1}, \mathrm{C} \cdot \mathrm{N}^{-1}\right.$ ratio of 285$)$ was used as the sole carbon source to cultivate the oleaginous molds M. isabellina ATHUM 2935 and Cunninghamella echinulata ATHUM 4411 resulting in lipid concentrations of $6.1 \mathrm{~g} \mathrm{~L}^{-1}$ and $6.7 \mathrm{~g} \mathrm{~L}^{-1}$ respectively at $360 \mathrm{~h}$, however, more than $25 \mathrm{~g} \mathrm{~L}^{-1}$ of unconsumed xylose remained in the media (Fakas et al., 2009). Dey et al. (2011) have reported lipid accumulations from xylose of $2.2 \mathrm{~g} \mathrm{~L}^{-1}$ for the oleaginous mold Colletotrichum sp.DM06, and $4.3 \mathrm{~g} \mathrm{~L}^{-1}$ for Alternaria sp.DM09 under nitrogen stressed conditions respectively. The oleaginous yeast Trichosporon cutaneum AS 2.571 assimilated glucose and xylose simultaneously, and accumulated intracellular lipid up to $59 \mathrm{wt} . \%$ with a lipid coefficient up to $0.17 \mathrm{~g} \mathrm{~g}^{-1}$ sugar, upon cultivation on a 2:1 glucose/xylose mixture (Hu et al., 2011).

Additionally, a variety of research has been conducted on oleaginous mold lipid accumulation from pretreated lignocellulosic biomass enzymatic hydrolysate. When using a mixture of wheat straw and bran as feedstock with solid culture, $80 \mathrm{mg}$ lipid per gram of dry solid cell mass ( $\mathrm{mg} \mathrm{gds}^{-1}$ ) was accumulated by the oleaginous mold Microsphaeropsis sp (Peng and Chen, 2008). For semisolid culture, $11 \mathrm{~g}$ oil $/ 100 \mathrm{~g}$ dry sweet sorghum was produced (Economou et al., 2010). Researchers using rice straw and wheat bran under solid culture produced $68.2 \mathrm{mg} \mathrm{gds}^{-1}$ and $60.32 \mathrm{mg} \mathrm{gds}^{-1}$ lipid using Colletotrichum sp. (DM06) and Alternaria sp. (DM09) (Dey et al., 2011). The mutant strain Mortierella. alpina (MAI502-8) accumulated 27.4 and $10.05 \mathrm{~g} \mathrm{~L}^{-1}$ cell mass and lipid respectively from a mixture of glucose and xylose media (5:3 wt/ wt) over 11 days of total culture time (Wang et al., 2011). Under varying $\mathrm{C} \cdot \mathrm{N}^{-1}$ ratios (35, 44 and 57), lipid accumulated in Mortierella isabellia ATHUM 2935 was 36\%, 51.2\% and 64.3\%, respectively using rice hull hydrolysate (Economou et al., 2011). However, limited studies exist which examine filamentous fungal lipid accumulation in submerged cultures using corn stover enzymatic hydrolysate after sulfuric acid or sodium hydroxide pretreatments. In this study, experiments were carried out in order to investigate the effects of different carbon sources on lipid accumulation using the oleaginous filamentous fungus $M$. isabellina under nitrogen stressed conditions. The carbon sources include: glucose, xylose, acid and alkaline pretreated corn stover coupled with enzymatic hydrolysis, as well as a glucose/xylose mixture acting as artificial hydrolysate.

\section{Methods}

\subsection{Microorganisms and culture conditions}

M. isabellina ATCC 42613 was obtained from the American Type Culture Collection (Manassas, VA). This strain was first cultured on potato dextrose agar (Sigma, USA) to produce spores at $30^{\circ} \mathrm{C}$. After 14 days cultivation, the spores were washed from the agar with sterile distilled water as a spore suspension and maintained at $4{ }^{\circ} \mathrm{C}$. Seed cultures were grown with $24 \mathrm{~g} \mathrm{~L}^{-1}$ potato dextrose broth (Sigma) with $8 \mathrm{~g} \mathrm{~L}^{-1}$ yeast extract at $25^{\circ} \mathrm{C}$ and $190 \mathrm{rpm}$ for 2 days in a rotary shaker (Thermal Scientific) with a spore concentration of 1 $2 \times 10^{7}$ spore $\mathrm{mL}^{-1}$. The submerged batch culture salt medium was: $\mathrm{KH}_{2} \mathrm{PO}_{4}\left(1 \mathrm{~g} \mathrm{~L}^{-1}\right)$ (Mallinckrodt Bakker); $\mathrm{MgCl}_{2} \cdot 6 \mathrm{H}_{2} \mathrm{O}\left(0.5 \mathrm{~g} \mathrm{~L}^{-1}\right)$ (Mallinckrodt Bakker); $\mathrm{ZnSO}_{4} \cdot 7 \mathrm{H}_{2} \mathrm{O} \quad\left(0.0014 \mathrm{~g} \mathrm{~L}^{-1}\right) \quad$ (Sigma); $\mathrm{MnSO}_{4} \cdot \mathrm{H}_{2} \mathrm{O}\left(0.0016 \mathrm{~g} \mathrm{~L}^{-1}\right)$ (Sigma); $\mathrm{CoCl}_{2} \cdot 6 \mathrm{H}_{2} \mathrm{O}\left(0.0036 \mathrm{~g} \mathrm{~L}^{-1}\right)$ (Sig$\mathrm{ma}) ; \mathrm{FeSO}_{4} \cdot 7 \mathrm{H}_{2} \mathrm{O}\left(0.00275 \mathrm{~g} \mathrm{~L}^{-1}\right)$ (Sigma); $2.74 \mathrm{~g} \mathrm{~L}^{-1}$ yeast extract (DOT Scientific Inc.) was used as the sole nitrogen source. The carbon sources used were glucose, xylose, artificial corn stover hydrolysate (composed of a mixture of glucose and xylose), and enzymatic hydrolysate of corn stover after sulfuric acid and sodium hydroxide pretreatments. The $\mathrm{pH}$ of the medium was adjusted to $6.0 \pm 0.1$ before autoclaving. Cultures were carried out at various initial sugar concentrations. For batch culture, $250 \mathrm{~mL}$ Erlenmeyer flasks were filled with $50 \mathrm{~mL}$ of growth medium and sterilized at $121{ }^{\circ} \mathrm{C}$ for $15 \mathrm{~min}$. The growth medium was inoculated with a $10 \%$ $\left(\mathrm{v} \mathrm{v}^{-1}\right)$ seed culture and cultivated at $25 \pm 1{ }^{\circ} \mathrm{C}$ on a rotary shaker (Thermal Scientific) with an agitation speed of $180 \mathrm{rpm}$.

\subsection{Enzymatic hydrolysates of corn stover after acid and alkaline pretreatments for filamentous fungal lipid production}

Corn stover was obtained from the Michigan State University Crop and Soil Science Teaching and Research Field Facility, and samples were air-dried and ground on site using a mill (Willey Mill, Standard Model No. 3, Arthur H. Thomas, Philadelphia, PA) with $2 \mathrm{~mm}$ size opening. Two different pretreatment methods were applied to the ground corn stover (Yue et al., 2010): dilute acid pretreatment $\left(1 \% \mathrm{w} \mathrm{w}^{-1} \mathrm{H}_{2} \mathrm{SO}_{4}, 121^{\circ} \mathrm{C}, 2 \mathrm{~h}, 10 \%\right.$ corn stover dry solid (ds)), and dilute alkaline pretreatment $\left(1 \% \mathrm{w} \mathrm{w}^{-1} \mathrm{NaOH}\right.$, $121^{\circ} \mathrm{C}, 2 \mathrm{~h}, 10 \%$ corn stover dry solid (ds)). After pretreatment, and without any detoxification, both samples were filtered with four layers of cheese cloth, and the hydrolysate liquids were neutralized using either $\mathrm{CaCO}_{3}$ or $\mathrm{H}_{2} \mathrm{SO}_{4}$ to a pH of $5 \pm 0.1$. The solid fiber and liquid samples were stored separately at $4{ }^{\circ} \mathrm{C}$ for later use.

For either sodium hydroxide treated corn stover (10.08 $\mathrm{g}$ dry matter) or sulfuric acid treatment ( $10.0 \mathrm{~g}$ dry matter), the corresponding liquid was centrifuged and added back to its respective residual fiber. The enzyme Accellerase $1000^{\circledR}$ was loaded at 26FPU g ${ }^{-1}$ dry fiber, and $0.05 \mathrm{M}$ citrate buffer $(\mathrm{pH} 4.8$ ) was added to create a $200 \mathrm{~g}$ solution ( $5 \%$ of dry matter in the solution) respectively. The solution was placed in a rotary shaker at $150 \mathrm{rpm}$ under $50{ }^{\circ} \mathrm{C}$ for $72 \mathrm{~h}$. After enzymatic hydrolysis, the hydrolysate was separated from the remaining fiber via centrifugation (3700 rpm $\times 20 \mathrm{~min}$ ) for further use in filamentous fungal lipid cultivation.

\subsection{Analytical methods}

Mycelia were collected by filtration and washed twice with distilled water. Cell mass was determined by drying under $105 \pm 1{ }^{\circ} \mathrm{C}$ overnight to get a constant weight. Glucose, xylose, cellobiose, arabinose, galactose, mannose, acetic acid, formic acid, furfural and hydroxymethylfurfural (HMF) were detected by an HPLC (Agilent 1100) equipped with a Bio-rad Aminex HPX-87H or 87P analytical column and a refractive index detector. The mobile phase was $0.005 \mathrm{M}$ sulfuric acid (flow rate of $0.6 \mathrm{~mL} \mathrm{~min}^{-1}$ ), and Milli-

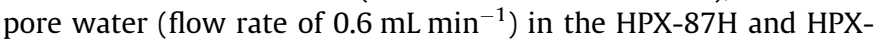
$87 \mathrm{P}$ columns respectively. Column temperatures were set to 65 and $60^{\circ} \mathrm{C}$ respectively. High purity glucose, xylose, cellobiose, arabinose, galactose, mannose, acetic acid, formic acid, furfural and HMF from sigma were used as the standards. Dried mycelia were ground in a mortar and used for lipid extraction following the method of Bligh and Dyer (Bligh and Dyer, 1959). Total lipid was determined gravimetrically. The extracted lipid was subjected to methanolysis to form fatty acid methyl esters (Indarti et al., 2005), which were analyzed by a gas chromatographer (Agilent) equipped with an Agilent J\&W DB-23 capillary column $(30 \mathrm{~m} \times 0.25 \mathrm{~mm})$. Helium was used as the carrier gas. The column temperature was programmed to $50^{\circ} \mathrm{C}$ for $2 \mathrm{~min}$, then raised to $180^{\circ} \mathrm{C}$ at an increasing rate of $10^{\circ} \mathrm{C} \cdot \mathrm{min}^{-1}$, held at $180^{\circ} \mathrm{C}$ for $5 \mathrm{~min}$, and then raised to $240{ }^{\circ} \mathrm{C}$ at an increasing rate of $5{ }^{\circ} \mathrm{C} \mathrm{min}{ }^{-1}$ and kept there for $1 \mathrm{~min}$. The injector (with injection volume of $1 \mu \mathrm{L}$ ) and FID detector temperatures were maintained at $240{ }^{\circ} \mathrm{C}$ and $280^{\circ} \mathrm{C}$, respectively. Methyl esters of myristic, palmitic, palmitoleic, stearic, oleic, linoleic, $\gamma$-linolenic acids, were used as standards for fatty acid identification and quantification. Protein and carbohydrate content of the filamentous fungal mycelia were analyzed according to the method of Bidochka with a slight mod- 
ification (Bidochka et al., 1990). For protein determination, $2.0 \mathrm{~mL}$ of $0.5 \mathrm{~mol} \mathrm{~L}^{-1} \mathrm{NaOH}$ was added to the $0.1 \mathrm{~g}$ mycelial samples in $20 \mathrm{~mL}$ glass vials, capped with aluminum slide caps, and placed in a boiling water bath for $15 \mathrm{~min}$. The tubes were cooled to $25^{\circ} \mathrm{C}$, and $0.50 \mathrm{~mL}$ of $1.0 \mathrm{~mol} \mathrm{~L}^{-1} \mathrm{HCl}$ and $0.50 \mathrm{~mL}$ of $0.1 \mathrm{~mol} \mathrm{~L}^{-1}$ Tris- $\mathrm{HCl}$ buffer ( $\mathrm{pH} 7.5$ ) were sequentially added. The protein concentration was estimated according to the BCA kit analysis method. For carbohydrate analysis, samples of mycelia were placed in test tubes and cooled on ice. A $5 \mathrm{~mL}$ sample of anthrone reagent ( $5 \mathrm{~mL}$ of absolute ethanol, $200 \mathrm{mg}$ of anthrone, $95 \mathrm{~mL}$ of $75 \%$ $\mathrm{w} \mathrm{w}^{-1} \mathrm{H}_{2} \mathrm{SO}_{4}$ ) was added to the $0.1 \mathrm{~g}$ dry mycelial samples in $20 \mathrm{~mL}$ glass vials, boiled for $10 \mathrm{~min}$, and then returned to an ice bath. After cooling the samples, the solution was measured at an absorption spectrum of $625 \mathrm{~nm}$; glucose was used as the standard.

\section{Results and discussion}

3.1. Effect of glucose and xylose concentration on cell mass production and lipid accumulation

M. isabellina ATCC42613 was cultured in nitrogen stressed medium at various initial glucose and xylose concentrations in order to examine changes in lipid accumulation in relation to cell mass production. Under fixed nitrogen conditions ( $2.74 \mathrm{~g} \mathrm{~L}^{-1}$ yeast extract), incremental increases in glucose and xylose concentrations resulted in gradual increases in cell mass production up to appreciable levels of $22.9 \mathrm{~g} \mathrm{~L}^{-1}$ and $21.6 \mathrm{~g} \mathrm{~L}^{-1}$ respectively without optimization of fermentation conditions. Lower initial sugar concentrations showed higher cell mass and lipid productivities (Table 1 ). The highest lipid $\left(10.2 \mathrm{~g} \mathrm{~L}^{-1}\right)$ and cell mass concentration $\left(22.9 \mathrm{~g} \mathrm{~L}^{-1}\right)$ for glucose both occurred at an initial C. $\mathrm{N}^{-1}$ ratio of 309.2. However, the highest lipid content (44.8\%) was seen at a $\mathrm{C} \cdot \mathrm{N}^{-1}$ ratio of 275.7 (Table 1 ). On xylose medium, the mold presented its highest lipid content (42.8\%) under an initial C. $\mathrm{N}^{-1}$ ratio of 110.3 , while the highest cell mass $\left(21.6 \mathrm{~g} \mathrm{~L}^{-1}\right)$ and lipid $\left(8.8 \mathrm{~g} \mathrm{~L}^{-1}\right)$ produced were observed under an initial C. $\mathrm{N}^{-1}$ ratio of 306.9.

Interestingly, it was observed that the percentage of lipid accumulated in cell mass kept quite constant $\left(Y_{\mathrm{L} / \mathrm{X}} 0.41-0.44 \mathrm{~g} \mathrm{~g}^{-1}\right.$ for glucose and $Y_{\mathrm{L} / \mathrm{X}} \quad 0.39-0.44 \mathrm{~g} \mathrm{~g}^{-1}$ for xylose respectively) during the entire range of initial glucose and xylose concentrations investigated. Similar results were obtained for M. isabellina ATHUM 2935 for lipid accumulation on high concentration of glucose media under nitrogen limited conditions, where lipid contents varied from $50 \%$ to $55 \%$ upon changing the $\mathrm{C} \cdot \mathrm{N}^{-1}$ molar ratios from 150:1 to 340:1 (Papanikolaou et al., 2004).
The final $\mathrm{pH}$ of the broth ranged from 5.2 to 5.8, showing a slight decrease from an initial $\mathrm{pH}$ of 6 in all growth conditions due to the production of organic acids (e.g. oxalic acid) in low concentrations.

\subsection{Effect of consumed $C / N$ ratio on mycelia growth and lipid production}

The sugar was rapidly consumed under low initial sugar concentrations (e.g. $28.1 \mathrm{~g} \mathrm{~L}^{-1}$ glucose or $26.6 \mathrm{~g} \mathrm{~L}^{-1}$ xylose) with a consumption rate of $0.41 \mathrm{~g} \mathrm{~L}^{-1} \mathrm{~h}^{-1}$ and $0.39 \mathrm{~g} \mathrm{~L}^{-1} \mathrm{~h}^{-1}$ respectively. However, the consumption rates for high initial glucose and xylose concentrations decreased, especially during the later growth stages, after long fermentation times (e.g. $408 \mathrm{~h}$ ), with $21.5 \mathrm{~g} \mathrm{~L}^{-1}$ glucose and $16.5 \mathrm{~g} \mathrm{~L}^{-1}$ xylose remaining unutilized at $82.5 \mathrm{~g} \mathrm{~L}^{-1}$ and $79.7 \mathrm{~g} \mathrm{~L}^{-1}$ initial glucose and xylose media respectively. Similar phenomena were also observed by other researchers (Certik and Shimizu, 2000; Gema et al., 2002; Fakas et al., 2009).

The filamentous fungus presented constant and impressive cell mass and lipid yields of $Y_{\mathrm{X} / \mathrm{S}}$ and $Y_{\mathrm{L} / \mathrm{S}}$ at $0.36 \mathrm{~g} \mathrm{~g}^{-1}$ and $0.14 \mathrm{~g} \mathrm{~g}^{-1}$ on glucose medium regardless of the initial glucose concentrations (Fig. 1a). Similar trends were observed on xylose medium; total cell mass and lipid yields were $0.30 \mathrm{~g} \mathrm{~g}^{-1}$ and $0.11 \mathrm{~g} \mathrm{~g}^{-1}$ respectively (Fig. 1b). However, other oleaginous Zygomycetes cultivated on glucose medium, presented significantly lower lipid yields (0.03$0.14 \mathrm{~g} \mathrm{~g}^{-1}$ ) compared with the strain under study (Kavadia et al., 2001; Gema et al., 2002). When cultured on xylose medium with a $C \cdot \mathrm{N}^{-1}$ ratio of 285 , the overall $Y_{\mathrm{L} / \mathrm{S}}$ of the mold $M$. isabellina ATHUM 2935 was 11.3\%; similar to our results (Fakas et al., 2009).

For glucose metabolism, the maximum theoretical lipid to glucose yield is $31 \%$. This study achieved a $14 \%$ conversion yield of lipid from glucose. Documented conversion yields above 20\% are rare, indicating there may be some limiting factor associated with this threshold for lipid accumulation from glucose (Fakas et al., 2009). Different yields in glucose (14\%) and xylose (11\%) cultures were observed in this study, indicating the possibility that xylose was metabolized through the pentose phosphate pathway, which is less efficient than glucose metabolism for lipid production in this filamentous fungus. Similar results were also observed by other researchers (Fakas et al., 2009).

\subsection{Intracellular lipid fatty acid profiles}

To evaluate the potential of using the filamentous fungal lipid as biodiesel substrate, its fatty acid profile was determined. FAME analysis indicated that the fatty acid compositions of the lipid from

Table 1

Cell mass and lipid accumulation of M. isabellina in medium with various initial glucose or xylose concentrations.

\begin{tabular}{|c|c|c|c|c|c|c|}
\hline Initial concentration $\left(\mathrm{g} \mathrm{L}^{-1}\right)$ & Initial $\mathrm{C} / \mathrm{N}^{\mathrm{a}}\left(\mathrm{mol} \mathrm{mol}^{-1}\right)$ & $\begin{array}{l}\text { Cell mass } \\
\left(X, \mathrm{~g} \mathrm{~L}^{-1}\right)\end{array}$ & $\begin{array}{l}\text { Lipid } \\
\left(L, \mathrm{~g} \mathrm{~L}^{-1}\right)\end{array}$ & $\begin{array}{l}\text { Yield }_{L / X} \\
\left(\mathrm{~g} \mathrm{~g}^{-1}\right)\end{array}$ & $\begin{array}{l}\text { Cell mass productivity } \\
\left(\mathrm{g} \mathrm{L}^{-1} \mathrm{~h}^{-1}\right)\end{array}$ & $\begin{array}{l}\text { Lipid productivity } \\
\left(\mathrm{g} \mathrm{L}^{-1} \mathrm{~h}^{-1}\right)\end{array}$ \\
\hline \multicolumn{7}{|l|}{ Glucose } \\
\hline 28.1 & 70.3 & $11.4 \pm 0.1$ & $5.0 \pm 0.3$ & $0.44 \pm 0.022$ & 0.20 & 0.088 \\
\hline 35.4 & 88.1 & $13.3 \pm 0.5$ & $5.5 \pm 0.0$ & $0.41 \pm 0.001$ & 0.14 & 0.059 \\
\hline 46.0 & 137.7 & $14.7 \pm 0.6$ & $5.9 \pm 0.6$ & $0.40 \pm 0.033$ & 0.088 & 0.035 \\
\hline 73.7 & 241.6 & $20.7 \pm 0.6$ & $8.9 \pm 0.5$ & $0.43 \pm 0.036$ & 0.051 & 0.022 \\
\hline 82.5 & 275.7 & $22.3 \pm 0.6$ & $10.0 \pm 1.8$ & $0.45 \pm 0.04$ & 0.055 & 0.025 \\
\hline 91.7 & 309.2 & $22.9 \pm 0.6$ & $10.2 \pm 0.2$ & $0.44 \pm 0.013$ & 0.051 & 0.023 \\
\hline \multicolumn{7}{|l|}{ Xylose } \\
\hline 26.6 & 66.8 & $9.8 \pm 0.2$ & $3.8 \pm 1.0$ & $0.39 \pm 0.1$ & 0.14 & 0.053 \\
\hline 39.1 & 110.3 & $11.4 \pm 0.3$ & $5.0 \pm 0.1$ & $0.43 \pm 0.002$ & 0.12 & 0.048 \\
\hline 45.7 & 136.9 & $14.2 \pm 1.0$ & $5.7 \pm 0.6$ & $0.40 \pm 0.023$ & 0.084 & 0.032 \\
\hline 66.3 & 212.5 & $17.5 \pm 2.5$ & $6.5 \pm 0.6$ & $0.37 \pm 0.052$ & 0.061 & 0.021 \\
\hline 79.7 & 266.4 & $18.9 \pm 0.6$ & $7.9 \pm 0.5$ & $0.42 \pm 0.034$ & 0.046 & 0.016 \\
\hline 90.9 & 306.9 & $21.6 \pm 1.1$ & $8.8 \pm 0.4$ & $0.41 \pm 0.024$ & 0.048 & 0.018 \\
\hline
\end{tabular}

Data points are the means of three replicate determinations with standard deviations.

a For initial C. $\mathrm{N}^{-1}$ ratio in the medium, it was assumed that yeast extract contained $12 \% \mathrm{w} \mathrm{w}^{-1}$ of carbon source and $7 \% \mathrm{w} \mathrm{w}^{-1}$ of nitrogen source. 

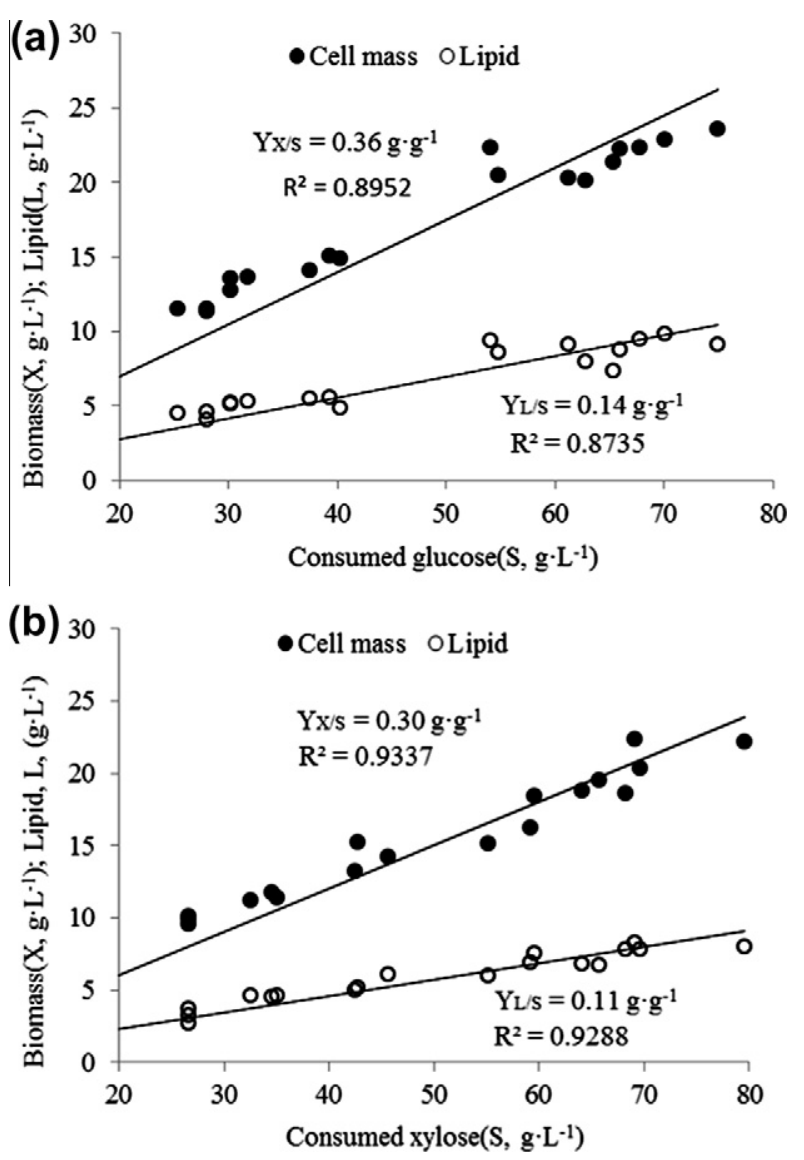

Fig. 1. Cell mass $\left(X, \mathrm{~g} \mathrm{~L}^{-1}\right)$ and stored lipid $\left(\mathrm{L}, \mathrm{g} \mathrm{L}^{-1}\right)$ produced by $M$. isabellina as function of consumed glucose (a) or xylose (b) in various initial sugar concentrations.

glucose and xylose were quite similar. In all cultures, it was observed that oleic acid (C18:1) was the dominant intracellular fatty acid. Palmitic acid (C16:0) was found to be the second most abundant fatty acid, whereas linolenic acid (C18:2) was present to a lesser degree. Traces of palmitoleic (C16:1), stearic (C18:0) and $\gamma$-linolenic acids (C18:3) were also found in the reserved lipid as well. The entire fatty acid profile present in the filamentous fungal lipid has potential utility for biodiesel production as has been documented for vegetable oils and fungi (Gopinath et al., 2009; Papanikolaou et al., 2004; Vicente et al., 2009).
Slight changes to the fatty acid composition in the stored lipid were observed regardless of the cultural conditions such as fermentation time or the initial glucose or xylose concentrations (Table 2), consistent with other reports (Papanikolaou et al., 2004). Oleic acid (C18:1) concentrations in glucose and xylose mediums ranged from $54.5-59.5 \%$ and $50.9-54.6 \%$ respectively, differing from other Zygomycetes cultivated on glucose medium, where the fatty acid composition of intracellular lipid varied significantly depending on the fermentation time (Kavadia et al., 2001).

\subsection{Prediction of biodiesel properties of the filamentous fungal lipids}

The iodine value, saponification value and higher heating values of the fatty acid methyl esters are important characteristics in determining the quality of the produced biodiesel. The iodine value is the amount of iodine (in grams) necessary to saturate $100 \mathrm{~g}$ of oil sample. Saponification values are milli-grams of $\mathrm{KOH}$ necessary to saponify $1 \mathrm{~g}$ of oil sample (Demirbas, 1998). Higher heating value is the amount of heat produced by the complete combustion of one gram of fuel including the latent heat of vaporization of water in the combustion products (Ramirez-Verduzco et al., 2012). These biodiesel values can be predicted from a given lipid source by using its fatty acid composition (C16:0, C18:0, C18:1, C18:2 and C18:3) as inputs into the predictive model (Gopinath et al., 2009).

Some variations in the filamentous fungal lipid iodine value were observed, ranging from 71.33 to $80.66 \mathrm{~g}$ iodine $/ 100 \mathrm{~g}$ oil and $68.24-80.12 \mathrm{~g}$ iodine/100 $\mathrm{g}$ oil for glucose and xylose cultures respectively. The saponification values and higher heating values were consistent regardless of the initial glucose or xylose concentrations in the medium (Fig. 2). The three chemical values of M. isabellina lipid were compared with the most commonly used lipid raw materials for biodiesel production: jatropha, palm, soybean and sunflower oils (Gopinath et al., 2009). It was found that the iodine and saponification values were within the range of these plant oils. The higher heating values were found to be quite similar with those plant oils as well.

\subsection{Effect of glucose and xylose concentration on cell mass composition}

Although extensive work has been performed on the accumulation of fungal lipids for fuel purposes, there seems to be limited information regarding the potential for byproduct extraction alongside biodiesel production. Solid byproducts would result from oil processing for biodiesel production. If not contaminated with toxic solvents such as hexane, they could be valuable sources of animal feed as they are rich in protein content (Khanal et al., 2008). Thus

Table 2

Effect of initial sugar concentrations on fatty acid composition of M. isabellina stored lipid.

\begin{tabular}{|c|c|c|c|c|c|c|c|}
\hline Initial sugar $\left(\mathrm{g} \mathrm{L}^{-1}\right)$ & $\mathrm{C} 16: 0$ & ${ }^{{ }^{9} \mathrm{C}} \mathrm{C} 16: 1$ & C18:0 & ${ }^{\Delta 9} \mathrm{C} 18: 1$ & ${ }^{\Delta 9,12} \mathrm{C} 18: 2$ & ${ }^{46,9,12} \mathrm{C} 18: 3$ & Others $^{\mathrm{a}}$ \\
\hline \multicolumn{8}{|l|}{ Glucose } \\
\hline 28.1 & $24.6 \pm 0.33$ & $2.49 \pm 0.01$ & $3.79 \pm 0.08$ & $54.5 \pm 0.28$ & $10.6 \pm 0.23$ & $3.08 \pm 0.02$ & $0.97 \pm 0.02$ \\
\hline 35.4 & $22.5 \pm 0.44$ & $2.62 \pm 0.05$ & $3.24 \pm 0.02$ & $55.5 \pm 0.61$ & $11.9 \pm 0.13$ & $3.09 \pm 0.05$ & $1.13 \pm 0.02$ \\
\hline 46 & $23.0 \pm 0.09$ & $1.99 \pm 0.06$ & $4.48 \pm 0.05$ & $55.6 \pm 0.60$ & $11.1 \pm 0.17$ & $2.78 \pm 0.05$ & $1.07 \pm 0.02$ \\
\hline 73.7 & $27.3 \pm 0.36$ & $2.53 \pm 0.04$ & $3.36 \pm 0.011$ & $54.0 \pm 0.67$ & $7.91 \pm 0.08$ & $2.25 \pm 0.02$ & $2.61 \pm 0.02$ \\
\hline 82.5 & $20.6 \pm 0.14$ & $2.51 \pm 0.05$ & $2.53 \pm 0.02$ & $59.5 \pm 0.77$ & $12.9 \pm 0.10$ & $0.36 \pm 0.01$ & $1.65 \pm 0.02$ \\
\hline 91.7 & $20.0 \pm 0.07$ & $2.32 \pm 0.04$ & $1.74 \pm 0.03$ & $58.4 \pm 0.70$ & $12.5 \pm 0.12$ & $3.21 \pm 0.041$ & $1.23 \pm 0.02$ \\
\hline \multicolumn{8}{|l|}{ Xylose } \\
\hline 26.6 & $23.7 \pm 0.29$ & $2.61 \pm 0.01$ & $4.32 \pm 0.07$ & $53.9 \pm 0.42$ & $11.4 \pm 0.15$ & $2.81 \pm 0.07$ & $1.29 \pm 0.05$ \\
\hline 39.1 & $24.6 \pm 0.33$ & $2.85 \pm 0.07$ & $3.59 \pm 0.06$ & $50.9 \pm 0.57$ & $13.0 \pm 0.25$ & $3.41 \pm 0.02$ & $1.65 \pm 0.03$ \\
\hline 45.7 & $29.6 \pm 0.16$ & $2.83 \pm 0.04$ & $3.60 \pm 0.05$ & $54.5 \pm 0.75$ & $7.10 \pm 0.08$ & $1.65 \pm 0.01$ & $0.72 \pm 0.02$ \\
\hline 66.3 & $21.5 \pm 0.28$ & $3.29 \pm 0.04$ & $2.29 \pm 0.04$ & $54.6 \pm 0.56$ & $13.7 \pm 0.07$ & $3.43 \pm 0.06$ & $1.18 \pm 0.02$ \\
\hline 79.7 & $24.2 \pm 0.23$ & $3.51 \pm 0.07$ & $2.23 \pm 0.01$ & $54.1 \pm 0.65$ & $11.9 \pm 0.05$ & $3.47 \pm 0.03$ & $0.56 \pm 0.08$ \\
\hline 90.9 & $25.6 \pm 0.15$ & $3.59 \pm 0.08$ & $2.44 \pm 0.26$ & $52.7 \pm 0.67$ & $10.8 \pm 0.08$ & $2.87 \pm 0.05$ & $2.07 \pm 0.04$ \\
\hline
\end{tabular}

Data points are the means of three replicate determinations with standard deviations.

a Others are C14:0, C20:0, C20:1 

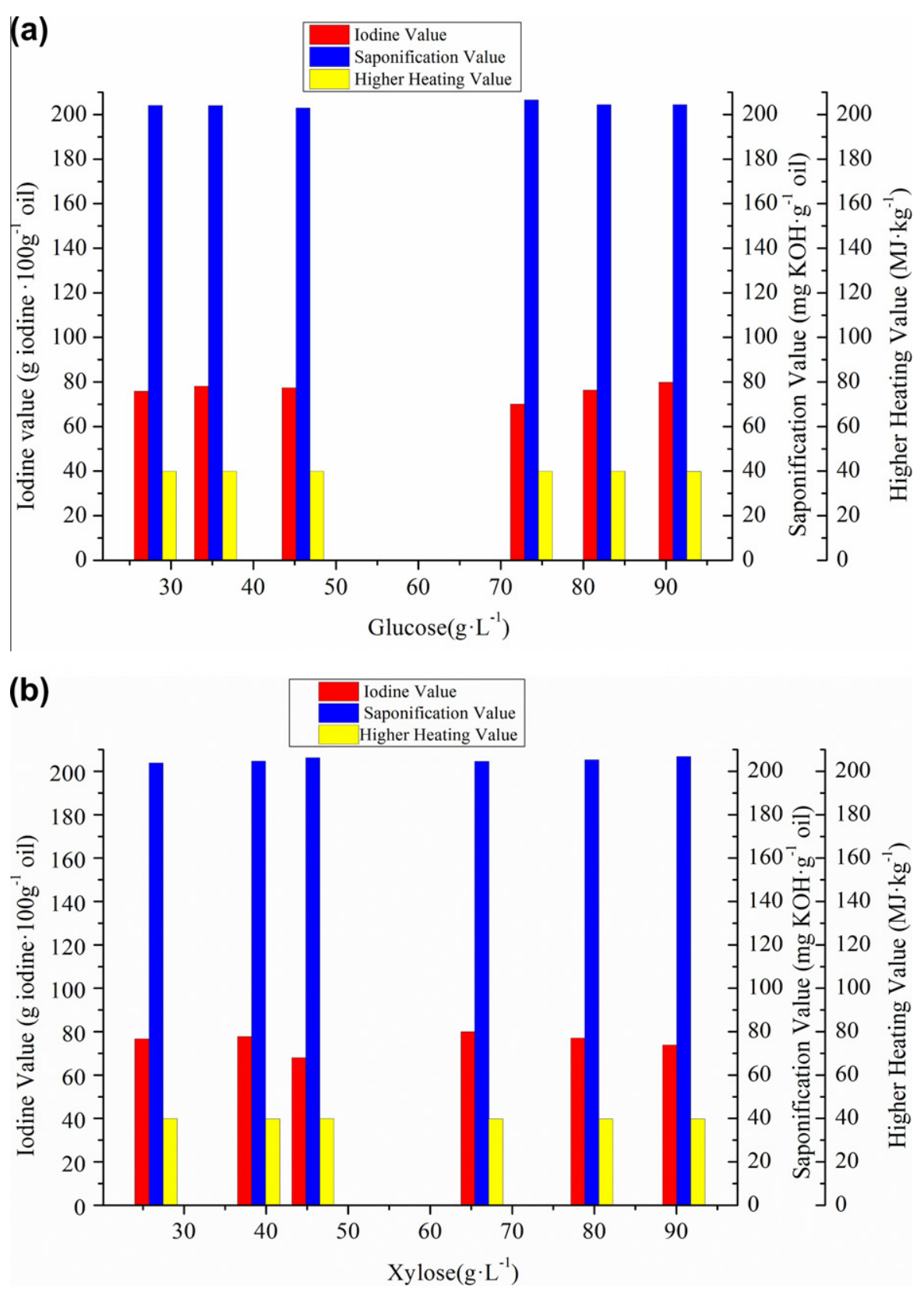

Fig. 2. Chemical properties of M. isabellina lipid from glucose (a) and xylose (b) for biodiesel production.

it is necessary to investigate the cell mass composition for a better understanding and utilization of these fungal biodiesel byproducts. Fig. 3a and b shows the mycelia lipid, protein, and carbohydrate content of $M$. isabellina grown on nitrogen stressed conditions with various initial concentrations of glucose or xylose as carbon source.

Along with consistency in its lipid production $\left(41-44 \% \mathrm{w} \mathrm{w}^{-1}\right.$ of the cell mass as intracellular lipid), the filamentous fungus also produced relatively constant carbohydrate $\left(4.28-7.75 \mathrm{~g} \mathrm{~L}^{-1}\right)$ and protein (1.4-2.2 $\mathrm{g} \mathrm{L}^{-1}$ ) amounts when cultured on glucose medium under experimental conditions. Similar results were seen with various initial xylose concentrations, as $4.15-6.96 \mathrm{~g} \mathrm{~L}^{-1}$ carbohydrate and $1.17-1.78 \mathrm{~g} \mathrm{~L}^{-1}$ protein were accumulated in the filamentous fungal cell mass respectively.

\subsection{Evaluation of lignocellulosic hydrolysates on lipid production}

Lignocellulosic material (corn stover) was evaluated for its potential use in lipid production by cultivating $M$. isabellina on its hydrolysate pretreated under both dilute acid and alkaline conditions. As a comparison, artificial media containing no inhibitors was also prepared with glucose and xylose concentrations mimicking those found in both the acid and alkaline pretreated enzymatic hydrolysate. $2.74 \mathrm{~g} \mathrm{~L}^{-1}$ of yeast extract was added to all media for a $C \cdot \mathrm{N}^{-1}$ ratio of approximately $73 \pm 4\left(\mathrm{~mol} \mathrm{~mol}^{-1}\right)$. The acid hydrolysate had a lower glucose concentration $\left(17.0 \mathrm{~g} \mathrm{~L}^{-1}\right)$, and higher xylose concentration $\left(14.0 \mathrm{~g} \mathrm{~L}^{-1}\right)$ than alkaline hydrolysate $(24.0 \mathrm{~g}$ $\mathrm{L}^{-1}$ glucose, and $6.4 \mathrm{~g} \mathrm{~L}^{-1}$ xylose respectively). The artificial and authentic corn stover hydrolysate sugar concentrations and fermentation results regarding cell mass, lipid, and lipid productivity of M. isabellina cultivation on these four substrates are shown in Table 3.

Degradation products from chemical pretreatment of biomass usually include the following classes of inhibitors: carboxylic acids, furans, phenols and inorganic salts, with phenols showing the greatest negative effect on fermentation. Low molecular weight (MW) organic salts are able to penetrate cell membranes, whereas 

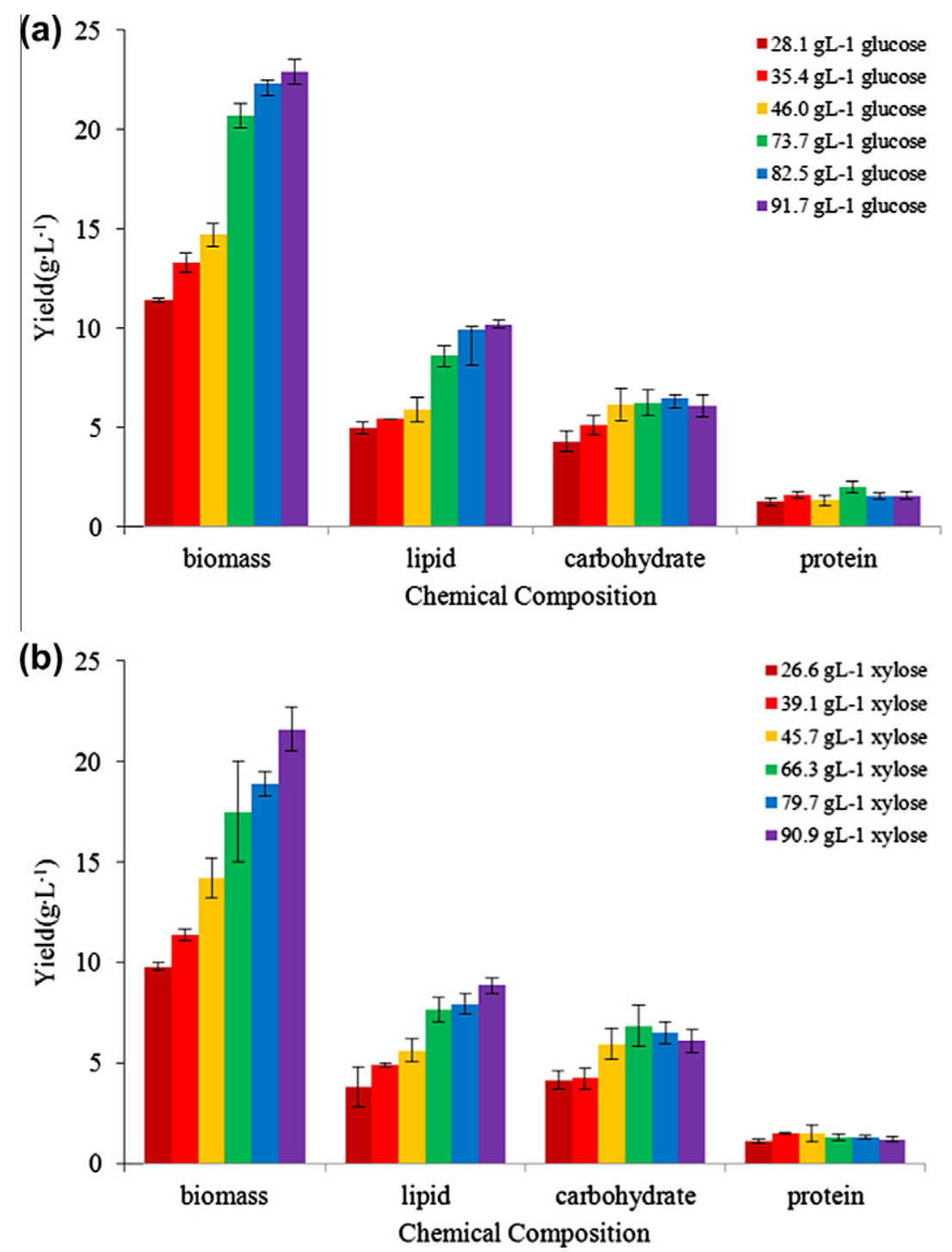

Fig. 3. Effect of various initial glucose (a) or xylose (b) concentrations on $M$. isabellina dry cell mass composition.

Table 3

Cell mass and lipid accumulation of M. isabellina using diluted acid and alkaline treated corn stover enzymatic hydrolysate and synthetic medium.

\begin{tabular}{|c|c|c|c|c|c|c|c|}
\hline Carbon source & $\begin{array}{l}\mathrm{C} \cdot \mathrm{N}^{-1 \mathrm{a}} \\
\left(\mathrm{mol} \mathrm{mol}^{-1}\right)\end{array}$ & $\begin{array}{l}\text { Glucose } \\
\left(\mathrm{g} \mathrm{L}^{-1}\right)\end{array}$ & $\begin{array}{l}\text { Xylose } \\
\left(\mathrm{g} \mathrm{L}^{-1}\right)\end{array}$ & $\begin{array}{l}\text { Cell mass } \\
\left(X, \mathrm{~g} \mathrm{~L}^{-1}\right)\end{array}$ & $\begin{array}{l}\text { Lipid ( } L \\
\left.\mathrm{~g} \mathrm{~L}^{-1}\right)\end{array}$ & $\begin{array}{l}\text { \%Yield } \\
\left(\mathrm{g} \mathrm{g}^{-1}\right)\end{array}$ & $\begin{array}{l}\text { Lipid productivity } \\
\left(\mathrm{g} \mathrm{L}^{-1} \mathrm{~h}^{-1}\right)\end{array}$ \\
\hline Synthetic Acid Hydrolysate & 77.4 & $16.85 \pm 0.13$ & $14.14 \pm 0.42$ & $12.59 \pm 0.15$ & $4.82 \pm 0.01$ & $38.36 \pm 0.23$ & 0.067 \\
\hline Acid Hydrolysate & 77.4 & $17.0 \pm 0.1$ & $14.0 \pm 0.1$ & $14.08 \pm 0.18$ & $4.78 \pm 0.3$ & $34.47 \pm 2.13$ & 0.050 \\
\hline $\begin{array}{l}\text { Synthetic Alkaline } \\
\text { Hydrolysate }\end{array}$ & 75.7 & $24.0 \pm 0.2$ & $6.3 \pm 0.5$ & $12.24 \pm 0.05$ & $3.28 \pm 0.18$ & $30.16 \pm 1.51$ & 0.050 \\
\hline Alkaline Hydrolysate & 70.7 & $21.9 \pm 0.3$ & $6.4 \pm 0.1$ & $10.90 \pm 1.06$ & $2.48 \pm 1.13$ & $29.47 \pm 4.26$ & 0.027 \\
\hline
\end{tabular}

Data points are the means of three replicate determinations with standard deviations.

${ }^{a}$ For initial C. $\mathrm{N}^{-1}$ ratio in the medium, it was assumed that yeast extract contained $12 \% \mathrm{w} \mathrm{w}^{-1}$ of carbon source and $7 \% \mathrm{w} \mathrm{w}^{-1}$ of nitrogen source.

fermentation inhibitors with high MW influence the expression and activity of sugar and ion transporters in the cell membrane. The toxic effects of inhibitors such as acetic acid, furfural, and HMF produced during pretreatment of lignocellulosic biomass on microbial cell growth and metabolism of ethanologenic bacteria and yeasts is well studied (Klinke et al., 2004). Several reports also detail the negative influence inhibitors have on lipid accumulation by oleaginous yeasts (Chen et al., 2009; Hu et al., 2009; Huang et al., 2009, 2011). However, information regarding the effect these inhibitors have on oleaginous filamentous fungal lipid accumulation is quite limited.
The following potential inhibitors were present in the acid treated enzymatic hydrolysate: furfural $\left(0.073 \pm 0.024 \mathrm{~g} \mathrm{~L}^{-1}\right)$, hydroxymethylfurfural $\left(0.032 \pm 0.0052 \mathrm{~g} \mathrm{~L} \mathrm{~L}^{-1}\right)$, and acetic acid $\left(2.71 \pm 0.04 \mathrm{~g} \mathrm{~L}^{-1}\right)$. Even in the presence of these inhibitors and without any detoxification, the maximum filamentous fungal cell mass concentration was obtained with the acid pretreated enzymatic hydrolysate $\left(14.08 \mathrm{~g} \mathrm{~L}^{-1}\right)$, higher even than its artificial equivalent $\left(12.59 \mathrm{~g} \mathrm{~L}^{-1}\right)$. This may be due to the utilization of acetic acid (Chen et al., 2009) and small amounts of minor sugars (cellobiose, galactose and arabinose) present in the hydrolysate medium (Cheng 
Table 4

Lipid production of oleaginous molds in different fermentation conditions.

\begin{tabular}{|c|c|c|c|c|c|}
\hline Strain & Carbon source & Lipid $\left(\mathrm{g} \mathrm{L}^{-1}\right)$ & Lipid content (\%) & $\begin{array}{l}\text { Lipid productivity } \\
\left(\mathrm{g} \mathrm{L}^{-1} \mathrm{~h}^{-1}\right) \text { media }\end{array}$ & Reference \\
\hline Mortierella isabellina ATHUM2935 & $\begin{array}{l}\text { Glucose } \\
\text { Commercial glucose } \\
\text { Commercial fructose } \\
\text { Glucose } \\
\text { Xylose } \\
\text { Raw glycerol }\end{array}$ & $\begin{array}{l}18.1 \\
9.9 \\
7.4 \\
12 \\
6.1 \\
3.3\end{array}$ & $\begin{array}{l}50.4 \\
74 \\
61.2 \\
44.6 \\
64.2 \\
53.2\end{array}$ & $\begin{array}{l}0.072 \\
0.042 \\
0.018 \\
0.033 \\
0.017 \\
0.0092\end{array}$ & $\begin{array}{l}\text { Papanikolaou et al. (2004) } \\
\text { Chatzifragkou et al. (2010) } \\
\text { Chatzifragkou et al. (2010) } \\
\text { Fakas et al. (2009) } \\
\text { Fakas et al. (2009) } \\
\text { Fakas et al. (2009) }\end{array}$ \\
\hline Mortierella isabellina ATHUM2935 & Rice hull hydrolysate & 2.3 & 64.3 & 0.0096 & Economou et al. (2011) \\
\hline Cunninghamella echinulata ATHUM 4411 & $\begin{array}{l}\text { Glucose }+ \text { TWH } \\
\text { Xylose } \\
\text { Raw glycerol } \\
\text { Commercial glucose } \\
\text { Commercial fructose }\end{array}$ & $\begin{array}{l}7.8 \\
6.7 \\
2.0 \\
3.9 \\
3.6\end{array}$ & $\begin{array}{l}25 \\
53.6 \\
53.6 \\
30 \\
21\end{array}$ & $\begin{array}{l}0.046 \\
0.0186 \\
0.0056 \\
0.0126 \\
0.0089\end{array}$ & $\begin{array}{l}\text { Chen and Chang (1996) } \\
\text { Fakas et al. (2009) } \\
\text { Fakas et al. (2009) } \\
\text { Chatzifragkou et al. (2010) } \\
\text { Chatzifragkou et al. (2010) }\end{array}$ \\
\hline Cunninghamella echinulata CCRC31840 & Glucose & 8.03 & 26.9 & 0.024 & Chen and Chang (1996) \\
\hline Colletotrichum sp.DM06 & Xylose & 2.2 & 29.7 & 0.0092 & Dey et al. (2011) \\
\hline Alternaria sp.DM09 & Xylose & 4.3 & 41.3 & 0.018 & Dey et al. (2011) \\
\hline Epicoccum purpurascensAUMC5615 & Molasses & 26.8 & 80 & 0.079 & Koutb and Morsy (2011) \\
\hline A. oryzae $A-4$ & Wheat straw + bran & 62.9 (mg gds) & N.A. & $0.44\left(\mathrm{mg} \mathrm{g}^{-1} \mathrm{~h}^{-1}\right)$ & Lin et al. (2010) \\
\hline Microsphaeropsis sp. & Wheat straw + bran & 80 (mg gds) & 10.2 & $0.33\left(\mathrm{mg} \mathrm{g}^{-1} \mathrm{~h}^{-1}\right)$ & Peng and Chen (2008) \\
\hline Colletotrichum sp.DM06 & Rice straw + wheat bran & $68.2($ mg gds $))$ & N.A. & $0.28\left(\mathrm{mg} \mathrm{g}^{-1} \mathrm{~h}^{-1}\right)$ & Dey et al. (2011) \\
\hline Alternaria sp.DM09 & Rice straw + wheat bran & 60.3 (mg gds) & N.A. & $0.25\left(\mathrm{mg} \mathrm{g}^{-1} \mathrm{~h}^{-1}\right)$ & Dey et al. (2011) \\
\hline Mortierella isabellina ATHUM2935 & Sweet sorghum & 0.11 (g gds) & 25 & $0.055\left(\mathrm{~g} \mathrm{~g}^{-1} \mathrm{~h}^{-1}\right)$ & Economou et al. (2010) \\
\hline Mortierella isabellina ATCC42613 & $\begin{array}{l}\text { Glucose } \\
\text { Xylose } \\
\text { Acid } \mathrm{CSH}^{\mathrm{a}} \\
\text { Alkaline } \mathrm{CSH}^{\mathrm{b}}\end{array}$ & $\begin{array}{l}10.2 \\
8.8 \\
25.2\left(\mathrm{mg} \mathrm{gds}^{-1}\right) \\
16.1\left(\mathrm{mg} \mathrm{gds}^{-1}\right)\end{array}$ & $\begin{array}{l}44.5 \\
40.7 \\
34.4 \\
29.5\end{array}$ & $\begin{array}{l}0.023 \\
0.018 \\
0.05 \\
0.027\end{array}$ & $\begin{array}{l}\text { This study } \\
\text { This study } \\
\text { This study } \\
\text { This study }\end{array}$ \\
\hline
\end{tabular}

N.A.: Not available.

a $1 \%\left(w^{-1}\right)$ Sulfuric acid treated enzymatic corn stover hydrolysate.

b $1 \%\left(\mathrm{w} \mathrm{w}^{-1}\right)$ Sodium hydroxide treated enzymatic corn stover hydrolysate.

et al., 2008; Hu et al., 2009). The filamentous fungus consumed acetic acid and glucose simultaneously, with acetic acid depletion occurring at $40 \mathrm{~h}$ of the total $90 \mathrm{~h}$ of cultivation time. This indicates the possibility that acetic acid not only participates in cell mass growth, but may also contribute to the accumulation of microbial lipid for this particular mold (Chen et al., 2009; Fei et al., 2011). Despite a slightly decreased glucose consumption rate (data not shown), lipid production in the acid hydrolysate was equivalent to that found in the artificial hydrolysate $\left(4.78 \mathrm{~g} \mathrm{~L}^{-1}\right.$ versus $4.82 \mathrm{~g} \mathrm{~L}^{-1}$ respectively), which was also the maximum concentration found in all media. The slight decrease in lipid yield, cell mass productivity and lipid productivity may be due to the deleterious effects from the other inhibitors produced during acid pretreatment.

Furfural and HMF were not detected in the enzymatic hydrolysate of sodium hydroxide pretreated corn stover. Acetic acid and formic acid were present with concentrations of $3.47 \pm 0.05 \mathrm{~g} \mathrm{~L}^{-1}$ and $1.36 \pm 0.05 \mathrm{~g} \mathrm{~L}^{-1}$ respectively. Acetic acid and formic acid were also consumed simultaneously with the consumption of glucose, with depletion occurring within $60 \mathrm{~h}$ and $43 \mathrm{~h}$ respectively of the total 114 h cultivation time. The cell growth and glucose consumption rates in the alkaline hydrolysate were much lower compared to its artificial media (data not shown). Lower cell mass, lipid yield, lipid content and lipid productivity were also observed in the alkaline hydrolysate (data in Table 3), which may be due to the inhibitory effects of phenols and carboxylic acids present in the media (Klinke et al., 2004). Further investigation on the detailed impact of inhibitors such as acetic acid, formic acid, phenolic compounds on lipid accumulation of this filamentous fungus needs to be conducted.

The greater growth and lipid production in the acid treated hydrolysate compared to the alkaline treated hydrolysate may be attributed to the greater concentration of inhibitors and the pres- ence of sodium salts found in the later treatment. The composition of the carbon sources in the media may have also mitigated some of the adverse effects of the inhibitors resulting in greater growth and lipid production in the acid hydrolysate media. The effects of these inhibitors on growth and lipid production may vary not only with their concentrations in the media, but the composition of the media itself since glucose and xylose utilize different metabolic pathways which the inhibitors would alter to varying degrees (Zhang et al., 2011). These results show that carbon sources from lignocellulosic biomass can be used to cultivate $M$. isabellina and, without detoxification, produce equivalent fermentation products as cell mass and lipid compared to growth on synthetic media (glucose and xylose mixture). This leads to the prospects of using an already cheap and abundant carbon source for filamentous fungal lipid production, which is made even more attractive since costs associated with detoxification of inhibition products could possibly be minimized.

A number of researchers reported growing oleaginous molds on glucose, xylose and lignocellulosic biomass for lipid accumulation (Table 4). The current study indicates that M. isabellina ATCC42613 is one such microorganism of interest as it exhibited noticeable production of stored lipid on higher glucose or xylose medium.

\section{Conclusions}

The filamentous fungus $M$. isabellina ATCC 42613, when cultivated on various carbon sources under stressed nitrogen conditions, is not only able to generate significant amounts of mycelia and lipid, but can also stably convert glucose and/or xylose to cellular lipid at a constant conversion yield while maintaining a stable intracellular fatty acid profile with appreciable chemical properties 
for biodiesel application. Lipid and cell mass conversion yields of enzymatic hydrolysates of sulfuric acid pretreated corn stover without washing and detoxification show comparable results to artificial hydrolysate without any inhibitors, indicating the promising future of utilizing lignocellulosic biomass for lipid production from filamentous fungal cultivation.

\section{Acknowledgements}

The authors acknowledge the Mass Spectrometry Facility at Michigan State University for providing the lipid intracellular fatty acid composition analysis.

\section{References}

Al-Widyan, M.I., Al-Shyoukh, A.O., 2002. Experimental evaluation of the transesterification of waste palm oil into biodiesel. Bioresource Technology $85,253-256$

Bouaid, A., Martinez, M., Aracil, J., 2007. Long storage stability of biodiesel from vegetable and used frying oils. Fuel 86, 2596-2602.

Bligh, E.G., Dyer, W.J., 1959. A rapid method of total lipid extraction and purification. Canadian Journal of Biochemistry and Physiology 37, 911-917.

Bidochka, M.J., Low, N.H., Khachatourians, G.G., 1990. Carbohydrate storage in the entomopathogenic fungus Beauveria-Bassiana. Applied and Environmental Microbiology 56, 3186-3190.

Certik, M., Shimizu, S., 2000. Kinetic analysis of oil biosynthesis by an arachidonic acid-producing fungus, Mortierella alpina 1S-4. Applied Microbial Biotechnology $54,224-230$

Chatzifragkou, A., Fakas, S., Galiotou-Panayotou, M., Komaitis, M., Aggelis, G., Papanikolaou, S., 2010. Commercial sugars as substrates for lipid accumulation in Cunninghamella echinulata and Mortierella isabellina fungi. European Journal of Lipid Science and Technology 112, 1048-1057.

Chen, H.C., Chang, C.C., 1996. Production of gamma-linolenic acid by the fungus Cunninghamella echinulata CCRC 31840. Biotechnology Progress 12, 338-341.

Chen, X., Li, Z.H., Zhang, X.X., Hu, F.X., Ryu, D.D.Y., Bao, J., 2009. Screening of oleaginous yeast strains tolerant to lignocellulose degradation compounds. Applied Microbial Biotechnology 159, 591-604.

Cheng, K.K., Cai, B.Y., Zhang, J.A., Ling, H.Z., Zhou, Y.H., Ge, J.P., Xu, J.M., 2008 Sugarcane bagasse hemicellulose hydrolysate for ethanol production by acid recovery process. Biochemical Engineering Journal 38, 105-109.

Demirbas, A., 1998. Fuel properties and calculation of higher hearing values of vegetable oils. Fuel 77, 1117-1120.

Dey, P., Banerjee, J., Maiti, M.K., 2011. Comparative lipid profiling of two endophytic fungal isolates Colletotrichum sp. and Alternaria sp. having potential utilities as biodiesel feedstock. Bioresource Technology 102, 5815-5823.

Economou, C.N., Makri, A., Aggelis, G., Pavlou, S., Vayenas, D.V., 2010. Semi-solid state fermentation of sweet sorghum for the biotechnological production of single cell oil. Bioresource Technology 101, 1385-1388.

Economou, C.N., Aggelis, G., Pavlou, S., Vayenas, D.V., 2011. Single cell oil production from rice hulls hydrolysate. Bioresource Technology 102, 9737-9742.

Fakas, S., Papanikolaou, S., Batsos, A., Galiotou-Panayotou, M., Mallouchos, A Aggelis, G., 2009. Evaluating renewable carbon sources as substrates for single cell oil production by Cunninghamella echinulata and Mortierella isabellina. Biomass \& Bioenergy 33, 573-580.

Fei, Q., Chang, H.N., Shang, L.A., Choi, J.D.R., Kim, N., Kang, J., 2011. The effect of volatile fatty acids as a sole carbon source on lipid accumulation by Cryptococcus albidus for biodiesel production. Bioresource Technology 102, 2695-2701.
Gema, H., Kavadia, A., Dimou, D., Tsagou, V., Komaitis, M., Aggelis, G., 2002. Production of gamma-linolenic acid by Cunninghamella echinulata cultivated on glucose and orange peel. Applied Microbial Biotechnology 58, 303-307.

Gopinath, A., Puhan, S., Nagarajan, G., 2009. Theoretical modeling of iodine value and saponification value of biodiesel fuels from their fatty acid composition. Renewable Energy 34, 1806-1811.

Hu, C.M., Zhao, X., Zhao, J., Wu, S.G., Zhao, Z.B.K., 2009. Effects of biomass hydrolysis by-products on oleaginous yeast Rhodosporidium toruloides. Bioresource Technology 100, 4843-4847.

Hu, C.M., Wu, S.G., Wang, Q., Jin, G.J., Shen, H.W., Zhao, Z.B.K., 2011. Simultaneous utilization of glucose and xylose for lipid production by Trichosporon cutaneum. Biotechnology for Biofuels 4.

Huang, C., Zong, M.H., Wu, H., Liu, Q.P., 2009. Microbial oil production from rice straw hydrolysate by Trichosporon fermentans. Bioresource Technology 100, 4535-4538.

Huang, C., Wu, H., Liu, Q.P., Li, Y.Y., Zong, M.H., 2011. Effects of aldehydes on the growth and lipid accumulation of oleaginous yeast Trichosporon fermentans. Journal of Agricultural and Food Chemistry 59, 4606-4613.

Indarti, E., Majid, M.I.A., Hashim, R., Chong, A., 2005. Direct FAME synthesis for rapid total lipid analysis from fish oil and cod liver oil. Journal of Food Composition and Analysis 18, 161-170.

Kavadia, A., Komaitis, M., Chevalot, I., Blanchard, F., Marc, I., Aggelis, G., 2001. Lipid and gamma-linolenic acid accumulation in strains of zygomycetes growing on glucose. Journal of the American Oil Chemists Society 78, 341-346.

Khanal, S.K., Rasmussen, M., Shrestha, P., Van Leeuwen, H., Visvanathan, C., Liu, H., 2008. Bioenergy and biofuel production from wastes/residues of emerging biofuel Industries. Water Environment Research 80, 1625-1647.

Klinke, H.B., Thomsen, A.B., Ahring, B.K., 2004. Inhibition of ethanol-producing yeast and bacteria by degradation products produced during pre-treatment of biomass. Applied Microbial Biotechnology 66, 10-26.

Koutb, M., Morsy, F.M., 2011. A potent lipid producing isolate of Epicoccum purpurascens AUMC5615 and its promising use for biodiesel production. Biomass \& Bioenergy 35, 3182-3187.

Lee, Y.Y., Lyer, P., Torget, R.W., 1999. Dilute-acid hydrolysis of lignocellulosic biomass. Advances in Biochemical Engineering/Biotechnology 65, 93-115.

Lin, H., Cheng, W., Ding, H.T., Chen, X.J., Zhou, Q.F., Zhao, Y.H., 2010. Direct microbial conversion of wheat straw into lipid by a cellulolytic fungus of Aspergillus oryzae A-4 in solid-state fermentation. Bioresource Technology 101, 7556-7562.

Papanikolaou, S., Komaitis, M., Aggelis, G., 2004. Single cell oil (SCO) production by Mortierella isabellina grown on high-sugar content media. Bioresource Technology 95, 287-291.

Peng, X.W., Chen, H.Z., 2008. Single cell oil production in solid-state fermentation by Microsphaeropsis sp from steam-exploded wheat straw mixed with wheat bran. Bioresource Technology 99, 3885-3889.

Ramirez-Verduzco, L.F., Rodriguez-Rodriguez, J.E., Jaramillo-Jacob, A.D., 2012. Predicting cetane number, kinematic viscosity, density and higher heating value of biodiesel from its fatty acid methyl ester composition. Fuel 91, 102111.

Ratledge, C., 2004. Fatty acid biosynthesis in microorganisms being used for single cell oil production. Biochimie 86, 807-815.

Vicente, G., Bautista, L.F., Rodriguez, R., Gutierrez, F.J., Sadaba, I., Ruiz-Vazquez, R.M., Torres-Martinez, S., Garre, V., 2009. Biodiesel production from biomass of an oleaginous fungus. Biochemical Engineering Journal 48, 22-27.

Wang, P., Zhang, L.M., Zheng, Z.M., Wang, L., Wang, H., Yuan, C.L., Gong, G.H., 2011 Microbial lipid production by co-fermentation with Mortierella alpina obtained by ion beam implantation. Chemical Engineering \& Technology 34, 422-428.

Yue, Z.B., Teater, C., Liu, Y., MacLellan, J., Liao, W., 2010. A sustainable pathway of cellulosic ethanol production integrating anaerobic digestion with biorefining. Biotechnology and Bioengineering 105, 1031-1039.

Zhang, G.C., French, W.T., Hernandez, R., Alley, E., Paraschivescu, M., 2011. Effects of furfural and acetic acid on growth and lipid production from glucose and xylose by Rhodotorula glutinis. Biomass \& Bioenergy 35, 734-740. 